\title{
EDITORIAL
}

\section{The Relevance and Urgency of our Task}

Our mission is to contribute to non-violent conflict resolution and find solutions to the problems generated by corruption, social injustice, war and crime. We are not short of work.

Fraud and malpractice in banks and governments through immoral, yet legal, practices have left millions of families out of work and homeless. Acts of terrorism by fanatical groups claim innocent, civilian lives even in the world's safest countries. Security and defence are still rooted in barbaric and destructive methods. In some countries crime is legalized. Over $20 \%$ of world trade is linked to criminal activity. There is widespread money laundering, human trafficking and arms trade across borders. Dozens of wars are raging and there are hundreds of conflicts over sovereignty issues.

Furthermore, there is forced prostitution and child sex trafficking, genital mutilation, the slave trade, antidemocratic practices in certain political systems, the destruction of the environment and natural habitats, illegal expropriation of land and evictions that flout the law.

The Journal of Conflictology provides scientific solutions to transform security and defence policies, replacing the use of force with scientific knowledge to deal with conflict, hate and violence. We search for solutions and promote research for pragmatic and ethical responses to the problems of today. Thanks to the contributions of the people who collaborate with us, this knowledge can make our world a much better place, truly safer, freer and more just. 